MEDIKA ALKHAIRAAT : JURNAL PENELITIAN KEDOKTERAN DAN KESEHATAN 3(3): 99-104

e-ISSN: 2656-7822, p-ISSN: 2657-179X

\title{
PEMETAAN KASUS DBD DAN FAKTOR IKLIM DI KOTA MAKASSAR
}

\author{
Ika Handayani ${ }^{*}$, Mudyawati Kamaruddin ${ }^{2}$ \\ ${ }^{1}$ Akademi Kebidanan, Tahirah Al Baeti, Bulukumba, Sulawesi Selatan, Indonesia \\ ${ }^{2}$ Program Pascasarjana Ilmu Laboratorium Medik Universitas Muhammadiyah Semarang, Jawa \\ Tengah, Indonesia
}

*Corresponding author: Telp: +6285242810710, email: ikahanda2606@gmail.com

\begin{abstract}
ABSTRAK
Demam Berdarah Dengue (DBD) adalah penyakit menular yang disebabkan oleh virus dengue dan menjadi masalah kesehatan masyarakat yang utama dengan jumlah kasus yang semakin tinggi. Penelitian ini bertujuan untuk mengetahui hubungan faktor iklim dengan kasus DBD di Kota Makassar. Penelitian ini dilaksanakan di Kota Makassar, Provinsi Sulawesi Selatan. Jenis penelitian adalah observasional analitik menggunakan data sekunder dari Dinas Kesehatan dan BMKG Kota Makassar. Populasi adalah data faktor iklim di Kota Makassar. Data yang digunakan adalah data sekunder yang diperoleh dari instansi terkait, yaitu data kasus DBD diperoleh dari hasil pencatatan Dinas Kesehatan Kota Makassar tahun 2012-2016. Data dianalisis secara statistik dengan uji korelasi sperman. Data diproses menggunakan program SPSS 20 dan Arc-Map Sig 10.3. Hasil penelitian menunjukkan bahwa berdasarkan hasil uji statistik terdapat hubungan yang bermakna ( $\mathrm{p}$-value= $0.013<0.05)$ antara suhu udara dan angka insiden DBD di Kota Makassar; terdapat hubungan yang bermakna $(p$-value $=0.013<0.05)$ antara kelembaban udara dan angka insiden DBD di Kota Makassar; terdapat hubungan yang bermakna $(0.049<0.05)$ antara curah hujan dan angka insiden DBD di Kota Makassar.
\end{abstract}

Kata kunci: Pemetaan, Endemisitas, DBD

\section{ABSTRACT}

Dengue Hemorrhagic Fever (DHF) is an infectious disease caused by dengue virus and is a major public health problem with an increasing number of cases.This research aimed to investigate the correlation of the climate factors with DBD cases in Makassar city. The type of research used was observational analytical research using secondary data from the Health Department. This research was conducted in Makassar City, South Sulawesi Province. The type of research used was observational analytical research using secondary data from the Health Department and BMKG, Makassar. Population is data on climatic factors in Makassar City. The data used are secondary data obtained from related agencies, namely DHF case data obtained from the records of the Makassar City Health Office 2012-2016. Data were analyzed statistically by using the Sperman correlation test. The data were processed using SPSS 20 and Arc-Map Sig 10.3. The results showed that based on the results of statistical tests there was a significant relationship ( $p$-value $=0.013<0.05)$ between air temperature and the incidence of dengue fever in Makassar City; there is a significant relationship ( $p$ value $=0.013<0.05$ ) between humidity and the incidence of dengue fever in Makassar City; there is a significant relationship $(0.049<0.05)$ between rainfall and the incidence of dengue fever in Makassar City.

Keywords: Mapping, Endemicity, Dengue Hemorrhagic Fever

\section{PENDAHULUAN}

Demam berdarah dengue (DBD) adalah penyakit infeksi yang disebabkan oleh virus dengue yang mengakibatkan demam akut. ${ }^{1}$ Penularan DBD terjadi melalui gigitan nyamuk Aedes yang terinfeksi oleh virus dengue. Jumlah kasus DBD di Indonesia pada tahun 2014 menunjukkan bahwa 10 provinsi yang memiliki jumlah kasus terbanyak salah satunya adalah provinsi Sulawesi Selatan. ${ }^{2}$ Kota makassar merupakan ibu kota provinsi Sulawesi Selatan menjadi salah satu kota dengan kasus endemisitas tinggi dan cenderung fluktuatif dari tahun ke tahun.

Demam berdarah dengue (DBD) di Kota Makassar merupakan masalah kesehatan masyarakat dengan jumlah kasus 
setiap tahunnya. Menurut data yang tercatat dari Dinas Kesehatan Kota Makassar menunjukkan kasus DBD pada tahun 2013 kasus DBD sebanyak 265 penderita $\mathrm{IR}=18,82 / 100.000$ penduduk $\mathrm{CFR}=4,2$, pada tahun 2014 terjadi penurunan kasus DBD sebanyak 139 penderita $\mathrm{IR}=9,73 / 100.000$ penduduk $\mathrm{CFR}=0,7$, pada tahun 2015 terjadi peningkatan kasus DBD sebanyak 142 penderita $\mathrm{IR}=9,80 / 100.000$ penduduk $\mathrm{CFR}=$ 3,5 sedangkan pada tahun 2016 terjadi peningkatan kasus DBD sebanyak 227 penderita dengan kematian 2 orang $\mathrm{IR}=17,00 / 100.000$ penduduk $\mathrm{CFR}=0,8$. $^{2}$

Faktor yang berperan dalam peningkatan kasus DBD yaitu faktor iklim yang meliputi suhu, kelembaban, curah hujan. Menurut penelitian yang dilakukan oleh Xiaodong et al (2013), menunjukkan bahwa Kejadian DBD secara signifikan berhubungan dengan suhu, kelembaban, curah hujan ${ }^{3}$.

Berdasarkan hal tersebut maka peneliti bermaksud melakukan penelitian dengan tujuan untuk mengetahui hubungan faktor iklim dengan kasus DBD di Kota Makassar Tahun 2012-2016.

\section{METODOLOGI}

Jenis penelitian yang digunakan adalah observasional analitik dengan menggunakan data sekunder dari Dinas Kesehatan. Adapun variabel dalam penelitian ini yaitu faktor iklim (suhu udara, kelembaban udara, curah hujan).

Sampel dalam penelitian ini adalah kecamatan yang berada di Kota Makassar. Pengambilan sampel dilakukan dengan cara "Exhaustic sampling". Setiap kecamatan yang berada di Kota Makassar akan dijadikan sebagai sampel.

Data kasus DBD diperoleh dari hasil pencatatan Dinas Kesehatan Kota Makassar tahun 2012-2016. Data Iklim (Suhu, Kelembaban, Curah Hujan) di Kota Makassar diperoleh dari hasil pengukuran Badan Meteorologi dan Geofisika wilayah IV kota Makassar.

Data dianalisis secara spasial (pemetaan dengan metode gradasi warna) dan secara statistik univariat dengan frekuensi, bivariat dengan uji spearman data yang telah dianalisis akan disajikan dalam bentuk peta, tabel dan narasi.

\section{HASIL DAN PEMBAHASAN}

HASIL

Distribusi Frekuensi Penyakit DBD

\begin{tabular}{|c|c|c|c|c|c|}
\hline \multirow{3}{*}{ Bulan } & \multirow{2}{*}{\multicolumn{5}{|c|}{ Kasus DBD / Tahun }} \\
\hline & & & & & \\
\hline & 2012 & 2013 & 2014 & 2015 & 2016 \\
\hline Januari & 17 & 8 & 11 & 10 & 16 \\
\hline Februari & 16 & 18 & 13 & 22 & 30 \\
\hline Maret & 12 & 29 & 14 & 25 & 48 \\
\hline April & 6 & 38 & 19 & 17 & 36 \\
\hline Mei & 7 & 30 & 29 & 16 & 34 \\
\hline Juni & 10 & 41 & 12 & 16 & 24 \\
\hline Juli & 4 & 62 & 11 & 11 & 15 \\
\hline Agustus & 4 & 18 & 8 & 7 & 5 \\
\hline September & 3 & 9 & 8 & 7 & 3 \\
\hline Oktober & 2 & 3 & 5 & 5 & 5 \\
\hline November & 3 & 4 & 5 & 3 & 6 \\
\hline Desember & 2 & 5 & 4 & 3 & 6 \\
\hline Jumlah & 86 & 265 & 139 & 142 & 228 \\
\hline
\end{tabular}

Tabel 1 menunjukkan distribusi frekuensi kasus DBD selama tahun 2012-2015 (5 tahun), kasus tertinggi terjadi pada bulan Maret dengan rata-rata 26 kasus sedangkan kasus terendah terjadi pada bulan Oktober, November, Desember dengan 4 kasus. Terlihat bahwa kasus mulai meningkat pada bulan januari sampai bulan juli, kemudian kasus cenderung mengalami penurunan pada bulan agustus hingga pada bulan Desember. 
Tabel 2. Distribusi Frekuensi Suhu Udara Menurut Bulan dan Tahun di Kota Makassar Tahun 2012-2016

\begin{tabular}{cccccc}
\hline & \multicolumn{5}{c}{ Suhu Udara $\left({ }^{\circ} \mathrm{C}\right) /$ Tahun } \\
\cline { 2 - 6 } BLN & 201 & 201 & 201 & 2015 & 201 \\
& 2 & 3 & 4 & & 6 \\
\hline Jan & 26,8 & 26,7 & 26,4 & 26,6 & 28,3 \\
Feb & 26,8 & 27,2 & 26,9 & 26,9 & 27,5 \\
Mar & 26,8 & 27,6 & 27,3 & 27,2 & 28,1 \\
April & 27,4 & 28,0 & 27,7 & 27,5 & 28,3 \\
Mei & 27,6 & 27,6 & 28,2 & 28,0 & 28,7 \\
Juni & 27,1 & 28,0 & 27,7 & 27,3 & 28,0 \\
Juli & 26,6 & 26,9 & 27,3 & 27,0 & 27,4 \\
Ags & 27,1 & 27,1 & 27,0 & 27,2 & 27,8 \\
Sep & 27,9 & 28,4 & 27,6 & 27,7 & 28,3 \\
Okt & 28,7 & 28,3 & 28,9 & 29,2 & 28,1 \\
Nov & 28,4 & 28,1 & 28,6 & 29,2 & 28,3 \\
Des & 27,7 & 26,9 & 27,2 & 27,7 & 27,5 \\
\hline Jumlah & 328,9 & 330,8 & 330,8 & 331,5 & 336,3
\end{tabular}

Sumber : Data Sekunder telah diolah, 2017

Pada tabel 2 diatas menunjukkan bahwa rata-rata suhu udara tertinggi terjadi pada tahun 2016 dengan suhu udara $28,0^{\circ} \mathrm{C}$ sedangkan suhu udara terendah pada tahun 2012 dengan suhu udara $27,4{ }^{\circ} \mathrm{C}$. Untuk ratarata suhu udara tertinggi bulanan terjadi pada bulan Oktober dengan rata-rata suhu udara $28,6^{\circ} \mathrm{C}$ sedangkan rata-rata suhu udara terendah bulanan terjadi pada bulan Januari dan Juli dengan rata-rata suhu udara $27,0^{\circ} \mathrm{C}$.

Pada tabel 3 menunjukkan bahwa ratarata kelembaban udara tertinggi terjadi pada tahun 2016 dengan rata -rata 84\% sedangkan terendah pada tahun 2014 dan 2015 dengan rata-rata $79 \%$. Untuk rata-rata kelembaban udara tertinggi bulanan terjadi bulan Januari dengan rata-rata $89 \%$ sedangkan rata-rata kelembaban udara terendah bulanan terjadi pada bulan September dengan rata-rata $69 \%$.

Terlihat bahwa kelembaban udara terjadi peningkatan pada bulan januari-juli dimana pada bulan-bulan tersebut terjadi musim penghujan dan penurunan kelembaban udara pada bulan agustus-oktober dimana pada bulan tersebut terjadi musim kemarau hingga pada bulan november-desember terjadi peningkatan kembali dimana bulan-bulan tersebut termasuk bulan peralihan dari musim kemarau ke musim penghujan.

Tabel 3. Distribusi Frekuensi Kelembaban Udara Menurut Bulan dan tahun di Kota Makassar Tahun 2012-2016

\begin{tabular}{cccccc}
\hline \multirow{2}{*}{ BLN } & \multicolumn{6}{c}{ Kelembaban Udara $(\%) /$ Tahun } \\
\cline { 2 - 6 } & 2012 & 2013 & 2014 & 2015 & 2016 \\
\hline Jan & 87 & 92 & 89 & 89 & 87 \\
Feb & 88 & 89 & 86 & 87 & 90 \\
Mar & 88 & 86 & 85 & 87 & 90 \\
April & 83 & 86 & 84 & 85 & 87 \\
Mei & 83 & 84 & 82 & 82 & 83 \\
& & & & & \\
Juni & 79 & 83 & 83 & 84 & 83 \\
Juli & 81 & 83 & 78 & 75 & 81 \\
Ags & 72 & 73 & 74 & 69 & 76 \\
Sep & 69 & 71 & 63 & 64 & 79 \\
Okt & 74 & 75 & 62 & 62 & 85 \\
Nov & 84 & 80 & 75 & 79 & 87 \\
Des & 86 & 87 & 87 & 90 & 88 \\
\hline Jumlah & 972 & 986 & 946 & 950 & 1012
\end{tabular}

Sumber : Data Sekunder telah diolah, 2017

Pada tabel 4 menunjukkan rata-rata curah hujan tertinggi pada tahun 2014 curah hujan $283 \mathrm{~mm}$ curah hujan terendah pada tahun 2016 curah hujan $230 \mathrm{~mm}$.

Tabel 4. Distribusi Frekuensi Curah Hujan Menurut Bulan dan Tahun di Kota Makassar Tahun 2012-2016

\begin{tabular}{cccccc}
\hline BLN & \multicolumn{5}{c}{ Curah Hujan (mm) / Tahun } \\
\hline & 2012 & 2013 & 2014 & 2015 & 2016 \\
\hline Jan & 590 & 882 & 994 & 890 & 689 \\
Feb & 494 & 471 & 385 & 398 & 395 \\
Mar & 493 & 427 & 313 & 346 & 317 \\
April & 304 & 211 & 277 & 263 & 216 \\
Mei & 158 & 174 & 254 & 95 & 68 \\
Juni & 32 & 149 & 153 & 89 & 95 \\
Juli & 29 & 104 & 100 & 15 & 17 \\
Agus & 0 & 2 & 8 & 5 & 0 \\
Sep & 4 & 0 & 1 & 0 & 75 \\
Okt & 80 & 57 & 49 & 1 & 181 \\
Nov & 180 & 166 & 179 & 105 & 168 \\
Des & 684 & 597 & 678 & 672 & 539 \\
\hline Jumlah & 3048 & 3240 & 3391 & 2879 & 2760
\end{tabular}

Sumber : Data Sekunder telah diolah, 2017 
Rata-rata curah hujan tertinggi bulanan pada bulan Januari rata-rata curah hujan $809 \mathrm{~mm}$. rata-rata curah hujan terendah bulanan pada bulan Agustus rata-rata curah hujan $3 \mathrm{~mm}$.

\section{Pemetaan Spasial angka insiden DBD} tahun 2012-2016

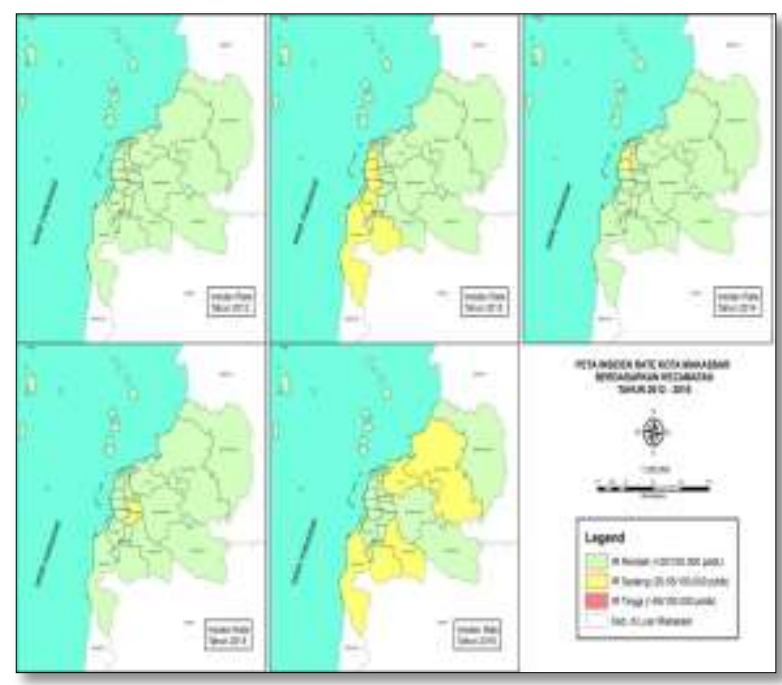

Berdasarkan gambar 13 klasifikasi angka insiden kasus DBD tahun 2012 dari 14 kecamatan yang berada di kota Makassar terdapat 14 kecamatan yang merupakan angka insiden kasus DBD berada pada kategori rendah. klasifikasi angka insiden kasus DBD tahun 2013 dari 14 kecamatan yang berada di kota Makassar terdapat 4 kecamatan yang merupakan angka insiden kasus DBD berada pada kategori sedang yaitu kecamatan ujung pandang, kecamatan mamajang, kecamatan rappocini, kecamatan manggala. 10 kecamatan yang merupakan angka insiden kasus DBD berada pada kategori rendah. klasifikasi angka insiden kasus DBD tahun 2014 dari 14 kecamatan yang berada di kota Makassar terdapat 1 kecamatan yang merupakan angka insiden kasus DBD berada pada kategori sedang yaitu kecamatan rappocini. klasifikasi angka insiden kasus DBD tahun 2015 dari 14 kecamatan yang berada di kota Makassar terdapat 1 kecamatan yang merupakan angka insiden kasus DBD berada pada kategori sedang yaitu kecamatan wajo.
Terdapat 13 kecamatan dalam kategori rendah. klasifikasi angka insiden kasus DBD tahun 2015 dari 14 kecamatan yang berada di kota Makassar terdapat 4 kecamatan yang merupakan angka insiden kasus DBD berada pada kategori sedang yaitu kecamatan mariso, panakkukang, manggala, biringkanaya. Sedangkan terdapat 10 kecamatan dalam kategori rendah.

Hasil uji statistik menunjukkan bahwa dalam kurung waktu 5 (Lima) tahun terakhir terdapat hubungan yang bermakna ( $p$-value $=0.013<0.05)$ antara suhu udara dengan kasus DBD. Hasil uji korelasi Spearman-rho menunjukan nilai " $\mathrm{r}=$ 0.645 " antara $0,51-0,75$ menunjukan bahwa kekuatan hubungan antara suhu udara dengan kasus DBD adalah hubungan kuat. Sedangkan arah korelasi dari suhu udara dengan kasus DBD adalah searah karena nilai "r" -(negatif) artinya jika suhu udara tinggi maka kasus DBD menurun. Korelasi Kelembaban Udara Dengan kasus DBD

Hasil uji statistik menunjukkan bahwa dalam kurung waktu 5 (lima) tahun terakhir terdapat hubungan yang bermakna $(p$-value $=0.013<0.05)$ antara Kelembaban udara dengan kasus DBD. Hasil uji korelasi Spearman-rho menunjukan nilai " $r=+0.645$ " antara 0,51 - 0,75 menunjukan bahwa kekuatan hubungan antara kelembaban udara dan kasus DBD adalah kuat. Sedangkan arah korelasi dari kelembaban udara dengan kasus DBD adalah searah karena nilai " $r$ " +(positif) artinya jika kelembaban udara tinggi maka kasus DBD juga tinggi.

Hasil uji statistik menunjukkan bahwa dalam kurung waktu 5 (lima) tahun terakhir terdapat hubungan yang bermakna ( $p$-value $=0.049<0.05)$ antara curah hujan dengan kasus DBD. Hasil uji korelasi Spearman-rho menunjukkan nilai " $\mathrm{r}=0.521$ " menunjukan bahwa kekuatan hubungan antara curah hujan dan kasus DBD adalah kuat. Sedangkan arah korelasi dari curah hujan dengan kasus DBD adalah searah karena nilai " $r$ " +(positif) artinya 
jika curah hujan tinggi maka kasus DBD tinggi.

\section{PEMBAHASAN}

\section{Hubungan Suhu Udara Dengan Kasus $D B D$}

Peningkatan dan penurunan kejadian kasus DBD di kota Makassar signifikan diikuti oleh suhu udara dimana Suhu udara dapat berpengaruh terhadap penyakit infeksi karena agen penyakit seperti bakteri, virus, parasit, dan vektor bersifat sensitif terhadap faktor iklim yang meliputi suhu, kelembaban, dan kondisi lingkungan ambien lainnya. Rata-rata suhu udara di Kota Makassar termasuk dalam kategori optimum untuk perkembangbiakan nyamuk. Secara spasial suhu udara $27^{\circ} \mathrm{C}$ terjadi pada kecamatan tamalate, rappocini, panakkukang, manggala, biringkanaya, tamalanrea sedangkan suhu udara $28^{\circ} \mathrm{C}$ terjadi pada kecamatan ujung tanah, tallo, bontoala, wajo, ujung pandang, makassar, mamajang, mariso. Berdasarkan rata-rata angka insiden DBD tahun 2012-2016 termasuk dalam kategori angka insiden rendah, berdasarkan rata-rata jumlah kasus, wilayah yang memiliki jumlah kasus tertinggi yaitu terdapat di kecamatan rappocini dengan kisaran suhu udara $27^{\circ} \mathrm{C}$ sedangkan kasus terendah terdapat pada wilayah kecamatan ujung tanah dengan kisaran suhu udara $28^{\circ} \mathrm{C}$. Hasil penelitian ini didukung oleh penelitian Xiadong et al (2013), yang menyatakan bahwa angka insiden DBD secara signifikan terkait dengan suhu udara di Cairns Autralia. ${ }^{3}$ Hasil penelitian ini tidak sejalan dengan penelitian Dini (2010), yang menyatakan tidak ada hubungan yang bermakna antara suhu dengan angka insiden DBD. ${ }^{4}$

\section{Hubungan Kelembaban Udara Dengan Kasus DBD}

Hasil penelitian ini mengartikan bahwa Kelembaban udara secara langsung berhubungan dengan kasus DBD, kelembaban berhubungan dengan umur perkembangbiakan nyamuk. Pada saat kelembaban optimum untuk perkembangbiakan nyamuk yakni $>60 \%$ maka umur nyamuk menjadi panjang sehingga berpotensi menjadi vektor penular penyakit DBD. Secara spasial ratarata kelembaban udara tertinggi terdapat pada wilayah kecamatan ujung tanah, tallo, bontoala, wajo, ujung pandang, makassar, mamajang, mariso dengan kelembaban udara rata-rata $80 \%$, kecamatan tamalate, rappocini, panakkukang, manggala, biringkanaya, tamalanrea dengan kelembaban udara rata-rata $82 \%$. Angka insiden DBD tertinggi terdapat pada wilayah dengan kelembaban udara $82 \%$ sedangkan angka insiden DBD terendah terdapat pada wilayah dengan kelembaban udara $80 \%$ hal ini berdasarkan uji statistik didapatkan nilai korelasi arah positif yang artinya semakin tinggi kelembaban maka semakin tinggi pula peningkatan kasus DBD. Hasil penelitian ini sejalan dengan penelitian yang dilakukan oleh Wirayoga (2013), menunjukkan bahwa terdapat hubungan antara kelembaban udara dengan kasus DBD.

\section{Hubungan Curah Hujan Dengan Kasus DBD}

Kasus DBD terjadi pada rata-rata curah hujan $\geq 200 \mathrm{~mm}$. Pada dasarnya curah hujan memberikan dampak terhadap meningkatnya jumlah vektor nyamuk aedes aegypti sehingga potensi penularan DBD di musim hujan juga tinggi. Curah hujan secara langsung dapat meningkatkan jumlah populasi vektor nyamuk karena banyaknya genangan air yang menjadi tempat perindukan nyamuk. Rata-rata curah hujan dalam kurung waktu 5 (lima) tahun terakhir tertinggi pada tahun 2014 (283) $\mathrm{mm}$ dan terendah pada tahun 2016 (230) $\mathrm{mm}$. Curah hujan bulanan tertinggi pada bulan januari $(809 \mathrm{~mm})$ terendah pada bulan Agustus (3mm). Terlihat bahwa jumlah kasus cenderung tinggi ketika musim hujan yaitu Januari-Juli dan cenderung mengalami penurunan pada bulan Agustus-Desember. Penelitian ini sejalan dengan penelitian yang dilakukan oleh Wirayoga (2013) yang menunjukkan 
bahwa terdapat hubungan dan signifikan antara curah hujan dengan kasus DBD di kota Semarang tahun 2006-2011. ${ }^{5}$ Penelitian ini sejalan tidak sejalan dengan penelitian yang dilakukan oleh Dini (2010), yang menyatakan bahwa tidak terdapat hubungan yang bermakna antara curah hujan dengan insiden DBD. Penelitian Apriliana (2017), di Kota Bandar Lampung Provinsi Lampung yang menyatakan bahwa tidak terdapat hubungan signifikan antara curah hujan dengan angka insiden penyakit DBD. ${ }^{6}$

\section{SIMPULAN DAN SARAN}

Penelitian ini menyimpulkan bahwa Pemetaan angka insiden DBD tahun 20122016 di kota Makassar terdapat 14 kecamatan termasuk dalam kategori angka insiden rendah. terdapat hubungan yang bermakna antara suhu udara dengan kasus DBD, terdapat hubungan yang bermakna antara kelembaban udara dengan kasus DBD, terdapat hubungan yang bermakna antara curah hujan dengan kasus DBD Penelitian ini menyimpulkan bahwa Pemetaan angka insiden DBD tahun 20122016 di kota Makassar terdapat 14 kecamatan termasuk dalam kategori angka insiden rendah.

\section{PERSANTUNAN}

Ucapan terima kasih saya hanturkan kepada semua pihak yang telah membantu dalam penyelesaian penelitian ini.

\section{DAFTAR PUSTAKA}

1. Arsin A.A. (2013). Epidemiologi Demam Berdarah Dengue (DBD) di Indonesia. Makassar : Masagena Press.

2. Dinas Kesehatan Kota Makassar. (2017). Data Penderita DBD di Kota Makassar. Kota Makassar.

3. Xiaodong H. et al. (2013). Imported Dengue Cases, Weather Variation and Autochthonous Dengue Incidence in Cairns, Australia. Diakses 28 februari 2017. Available from: (http://journals.plos.org/plosone/article ?id=10.1371/journal.pone. 0081887
4. Dini A.M.V. (2010). Faktor Iklim dan Angka Insiden Demam Berdarah Dengue di Kabupaten Serang. Diakses 20 Mei 2017. Available from: journal.ui.ac.id/index.php/health/articl e/viewFile/644/629

5. Wirayoga M.A. (2013). Hubungan Kejadian Demam Berdarah Dengue Dengan Iklim di Kota Semarang Tahun 2006-2011. Diakses 24 Februari 2017. Available from: (http://journal.unnes.ac.id/artikel_sju/uj $\mathrm{ph} / 3055$

6. Apriliana. (2017). Pengaruh Iklim Terhadap Kejadian Demam Berdarah Dengue di Kota Bandar lampung, Provinsi Lampung. Diakses 20 Mei 2017. Available from: http://www.kalbemed.com/Portals/6/1_ 06_250Pengaruh\%20Iklim\%20terhada p\%20Kejadian\%20DBD\%20di\%20Ba ndar\%20Lampung.pdf 